\title{
Iridium-Catalyzed Z-Retentive Asymmetric Allylic Substitution Reactions
}

\section{Key words}

iridium catalysis

enantioselectivity

Z-selectivity
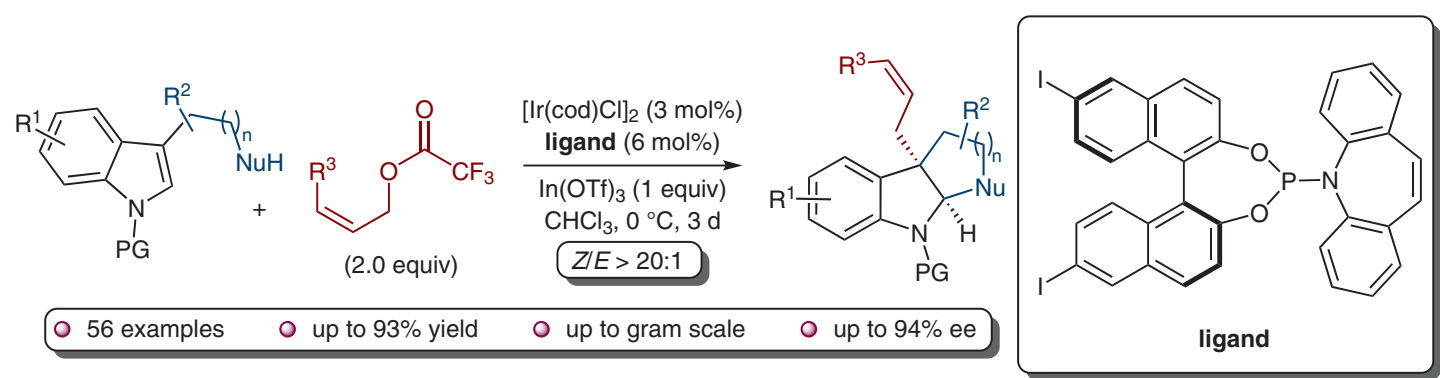
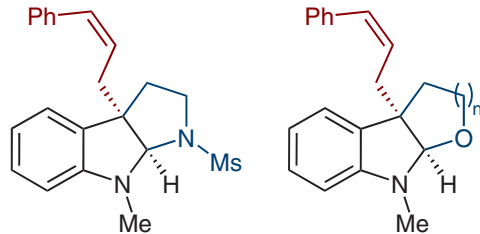

$\mathrm{Me}$

$76 \%$ yield, $92 \%$ ee $n=1,84 \%$ yield, $93 \%$ ee $\mathrm{n}=2,76 \%$ yield, $91 \%$ ee

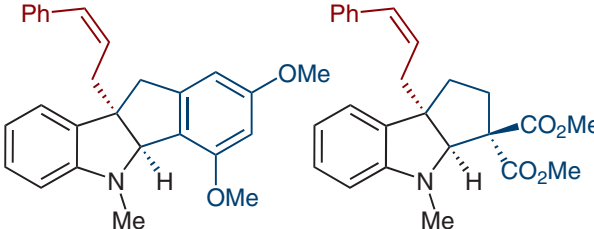

$78 \%$ yield, $85 \%$ ee

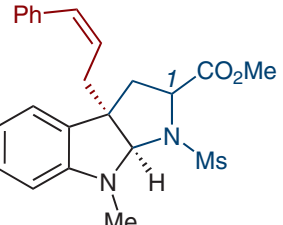

$88 \%$ yield, $84 \%$ ee $1(S)=71 \%$ yield, $d r=10: 1$<smiles>[R7]C/C=C\COC(C)=O</smiles>

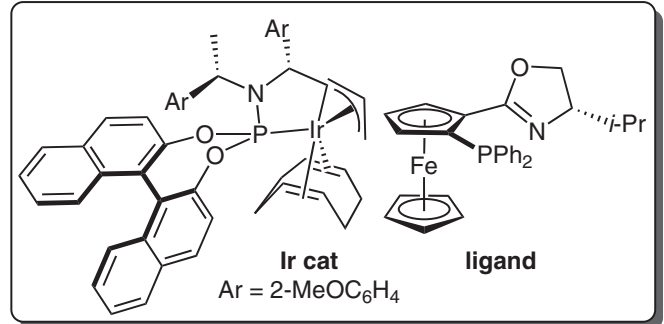

○ 34 examples o up to $97 \%$ yield 0 up to $0.2 \mathrm{mmol}$ scale $\bigcirc$ up to $>99 \%$ ee<smiles>CC(C)(C)OC(=O)[C@](C)(C/C=C\COc1ccccc1)NCc1ccccc1</smiles>

$95 \%$ yield, $>99 \%$ ee<smiles>CC(=O)OCCC[C@@](C/C=C\COc1ccccc1)(NCc1ccccc1)C(=O)OCc1ccccc1</smiles>

$70 \%$ yield, $96 \%$ ee<smiles>C=CCOC/C=C\C[C@](C)(NCc1ccccc1)C(C)=O</smiles>

$65 \%$ yield, $95 \%$ ee<smiles>CC(=O)[C@](C/C=C/COc1ccccc1)(Cc1ccccc1)NCc1ccc(Br)cc1</smiles>

$87 \%$ yield, $92 \%$ ee
Significance: The You group reports two unique methods for enantioselective iridium-catalyzed allylic substitution reactions, which are highly selective for the thermodynamically less stable Z-alkene products. Conventionally, metal-catalyzed asymmetric allylic substitution reactions favor the E-isomer of the products.
Comment: The authors rationalized their reaction design by focusing on developing a catalytic system that allowed for a slow isomerization from the initial anti- $\pi$-allyl complex to the more favored syn- $\pi$ allyl species. Subsequent capture of the chiral anti$\pi$-iridium species by a nucleophile selectively generated the enantioenriched $Z$-alkene products. 